\title{
Effects of Sowing Date on Physiological Characteristics, Yield and Yield Components for Different Maize (Zea mays L.) Hybrids
}

\author{
Amir Taher RAH KHOSRAVANI ${ }^{1}$, Cyrus MANSOURIFAR ${ }^{1}$, \\ Seyed Ali Mohammad MODARRES SANAVY ${ }^{2 *}$, Kamal Sadat ASILAN ${ }^{1}$, \\ Hamed KESHAVARZ ${ }^{2}$
}

\author{
${ }^{1}$ Payame Noor University, Faculty of Agriculture, Karaj, Iran \\ ${ }^{2}$ Tarbiat Modares University, Faculty of Agriculture, Agronomy Department, Tehran, Iran; modarresa@yahoo.com (*corresponding author)
}

\begin{abstract}
In order to determine the effects of sowing date on physiological characteristics, yield and yield components of six sweet maize hybrids, an experiment was arranged in split plot based complete randomized block design with three replications. Sowing date in two levels ( 15 June and 1 July) and sweet maize hybrids in six variants ('Chase', 'Temptation', 'Challenger', 'Basin', 'Obsession' and 'Ksc $403 \mathrm{su}$ ') were the treatments. Results of ANOVA revealed significant difference of sowing date and sweet maize hybrids on the number of days for tassel emergence, number of days to anthesis, plant height, cob height, stem diameter, plant dry weight, cob dry weight, number of grain rows, length flowers, number of leaf above the cob, raffinose content of grain and grain yield. Mean comparisons showed that the highest grain yield was obtained for 'Basin' variety and it was obtained from the crop established on the $15^{\text {th }}$ of June as planting date. In temperate regions, maize potential productivity seems to be more limited by the amount of solar radiation available around silking (determinant of grain set) than during grain filling (determinant of grain weight).
\end{abstract}

Keywords: physiological characteristics, sowing date, sweet maize, yield

\section{Introduction}

Fresh sweet corn (Zea mays L. var. saccharata) has been consumed broadly by boiling or by grilling since past times. Production and use of sweet corn has expanded rapidly in recent years. Sweet corn varies from other corns (field maize, popcorn and ornamental) since the grains have great sugar content in the milk on early dough stage. It is consumed in the immature stage of the crop. The taste of sweet corn kernels is 25-30\% sweeter than normal corn. At optimum market maturity, sweet corn will contain 5 to $6 \%$ sugar, 10 to $11 \%$ starch, 3\% water-soluble polysaccharides and $70 \%$ water. Sweet corn also has medium levels of protein, vitamin A (yellow varieties) and potassium (Najeeb et al., 2011). It can be consumed as fresh, frozen or conserved and also used particularly as garniture in the salads. Corn (Zea mays $\mathrm{L}$.) is one of the most important cereal crops grown principally during the summer in Iran. Is one of the important cereal crops in the world after wheat and rice (Gerpacio and Pingali, 2007; Golbashy et al., 2010). The International Maize and Wheat Improvement Centre (CIMMYT) accompany with National Agricultural Research Systems (NARS) routinely conducted maize regional trials with the objective of evaluating, selecting high yielding and stable genotypes in a wide range of environments (Banziger and De Meyer, 2002). Grzesiak (2001) reported remarkable genotypic variability among corn varieties for several characteristics. Ihsan et al. (2005) also demonstrated considerable genetic differences for morphological variables for corn genotypes. This mutability is a clue to crop improvement (Welsh, 1981).

Environmental variations related with different sowing dates have an altering effect on the growth and development of corn plants. Each corn hybrid has a desirable planting date, and the larger the deflection from this favorite (early or late planting), the larger the yield loss (Sárvári and Futó, 2000; Berzsenyi and Lap, 2001). Sowing date was introduced to affect the growth and yield of corn significantly. To date, compete for corn growers is finding the thin window between cultivation too early and cultivation too late (Nielson et al., 2002). Either early cultivation or late cultivation can result in lower yield since the probability exists that unfair climatic conditions can happen after cultivation or during the growing season. Norwood (2001) suggested that farmers should plant on more than one sowing date in order to protect against unforeseen seasons. Short season hybrids can be cultivated early without harmful effects on their upmost yield potential. It can also minimize the risk of obtaining immature cobs and grains or sustaining early frost loss (Hicks et al., 1993). 
144

The environmental and agronomic respond of corn hybrids recognize their adaptability and influence improvements in corn production through agronomy and breeding. Newly improved varieties usually need to be examined at several sowing dates or locations and for many years before being counseled for a given location. The basic environmental effects and genotype environment interaction have been introduced as the most important sources of alteration for the measured yield of crops (Dehghani et al., 2006; Yan et al., 2007; Sabaghnia and Sabaghpour, 2008). The yield of maize in Iran is very little (Xue et al., 2002). Maize undergoes three stages from pollen dissemination to physiological maturation (Johnson and Tanner, 1972; Cox et al., 1998). The first stage is known as lag phase (slow growth), the cells start to divide (Duvick, 1951; Abdul et al., 2001). At the end of this stage, grain weight slightly increases since endosperm cells play an important role in sink capacity (Outtar et al., 1987; Ahmad et al., 2001). The second stage is known as grain linear filling (log phase), the stage of sharp increase in grain dry weight due to the conversion of sugar to starch in endosperm, which commences 2-3 weeks after tassel emergence. Over $90 \%$ of grain dry weight is realized in this stage (Johnson and Tanner, 1972; Cox et al., 1998). During this stage, grains grow with a speed of $2-3 \%$ of final yield per day.

The most important effective factors on grain yield are application of optimal maize hybrids and suitable sowing dates. The research works focused more on breeding aspects rather than crop management (Xue et al., 2002). Under the optimum planting time for maize conditions, would be from the last week of September to the end of October in Khartoum area. High grain yield $\left(2,952 \mathrm{~kg} \mathrm{ha}^{-1}\right)$ was obtained during this period (Imam, 1966). The period from November to February is the best time for the highest dry matter production in the Khartoum area. It was also reported that the mean daily temperature is the major environmental factor that affects the crop development and yield (Elkarouri and Mansi, 1980; Begna et al., 2000). Grain yield maize was reduced when sowing time was delayed to the end of October (Mc Cormick, 1974). Delaying sowing date to mid-December reduced the individual 1,000 kernel weight (Cirilo and Andrade, 1996); the authors also indicated that maize varieties differed in their growth characters in Gainesville Florida (El-Koomy, 2005; Gardner et al., 1990). It has been shown that July 15 is an optimal sowing date for maize in Peshawar (Ahmad et al., 2001). In India, Sadek et al. (1994) and Zaki et al. (1999) reported that maize cultivars differed in yield and its components in the same region.

Variation in biological yield of corn varieties at different planting dates was associated with differences in the amount of intercepted radiation. Shorter cultivars had greater assimilated allocation to the grain than the taller cultivars (Benga et al., 2000). Grain growth rate is directly associated with dominant temperature and largely independent of dry matter accumulation in final crop (Duncan et al., 1965). If kernel growth outruns dry matter accumulation in the final crop, its required dry matter will be supplied and remobilized from stalks, leaves and cob covers (mostly from stalks). The third stage is accompanied with a decrease in dry matter accumulation in kernels and comes to an end with physiological maturation. Kernel weight is also determined in this stage. However, an important effect of temperature is that higher temperature (especially at night) shortens grain filling period and increases grain filling rate, while lower temperature have an inverse effect (Jones et al., 1981). Therefore, the present work was carried out to study the effect of sowing date and cultivar on grain yield of sweet corn.

\section{Materials and Methods}

The experiment was accomplished at Agricultural Research Center of Karaj, Iran. Soil preparation operations included plowing by moldboard plow, completing it by disc and leveling. Before carrying out the experiment, the soil was sampled from the depth of $0-30 \mathrm{~cm}$. The experiment was carried out on clayloam soil (Table 1). The results of soil analysis indicated that the absorbable phosphorus and carbon were $81.15 \mathrm{ppm}$ and $81 \%$ respectively, and its $\mathrm{pH}$ was 7.61 . The Meteorological information of Karaj is shown in Table 2. The previous crop was wheat. The soil was fertilized by $350 \mathrm{~kg}$ Urea/ha $(1 / 3$ during sowing, $1 / 3$ at six leaf stage and the remaining during tassel emergence as top-dressing), $180 \mathrm{~kg} \mathrm{~K} 2 \mathrm{O} / \mathrm{ha}$, and $150 \mathrm{~kg}$ $\mathrm{P}_{2} \mathrm{O}_{5} /$ ha after leveling and before making the furrows. Six varieties namely 'Chase,' 'Temptation', 'Challenger', 'Basin', 'Obsession' and 'Ksc403su' were sown in two dates: 15 June and 1 July 2014. The experiment was arranged in split plot based complete randomized block design with three replications. Main factors were sowing date at two levels (15 June and 1 July) and sub plots were the six cultivars. Spacing of $75 \mathrm{~cm}$ row to row and $18 \mathrm{~cm}$ plant to plant spacing was maintained and two seeds were sown at the depth of $5 \mathrm{~cm}$; at four-leaf stage, one plant with the best development, was kept and the other was eliminated. Plot size was $6 \times 3.6 \mathrm{~m}$, out of which $5 \times 2.4$ was used to assess final harvest. The furrow irrigation was applied twice a week. Data were collected when each cultivar, for both planting dates, was judged to be at optimum fresh market maturity.

Measurements were made immediately after harvest. All morphological and yield component traits were measured on 10 randomly selected plants of each plot. Ten ears per replication were randomly selected and husked for the length, width and ear tip fill measurements. The number of days until $50 \%$ crop tasseling, 50\% silking and 5\% pollination were recorded. Sweet corn growths in height and leaf number, as a function of thermal time, were determined for each plot. To evaluate the effect of planting date on sweet corn establishment, growth and yield, the additional variables measured after crop emergence, near silk emergence and at harvest were subjected to ANOVA and means separation. Yield was measured in $3 \mathrm{~m}^{2}$ for each treatment. Fresh ears were immediately husked with a husking bed (Sweet Corn Husker; A\&K Development Co., Eugene, OR) and kernels were removed from the cob with an industry-grade corn cutter. Husked mass and kernel mass were recorded and adjusted to $15 \%$ moisture level. Ten ears per replication were randomly selected and husked for the length, width and ear tip fill measurements. The data statistical analysis was done by SAS statistical software (SAS, 2002) and the comparison of mean was also done by LSD test at $5 \%$ probability level. 
Table 1. Physical and chemical properties of soil $(0-30 \mathrm{~cm})$

\begin{tabular}{|c|c|c|c|c|c|c|c|}
\hline \multirow{2}{*}{ Soil texture } & Clay & Silt & Sand & Organic matter & $\mathrm{pH}$ & $\mathrm{EC}$ & Total nitrogen \\
\hline & $\%$ & $\%$ & $\%$ & $\%$ & & $\left(\mathrm{~d} S \mathrm{~m}^{-1}\right)$ & $\%$ \\
\hline Clay -loam & 36 & 34 & 30 & 81 & 7.61 & 4 & 0.079 \\
\hline
\end{tabular}

Table 2. Meteorological information of the study area

\begin{tabular}{ccccc}
\hline Month & $\begin{array}{c}\text { Maximum relative } \\
\text { humidity }(\%)\end{array}$ & $\begin{array}{c}\text { Minimum relative } \\
\text { humidity }(\%)\end{array}$ & $\begin{array}{c}\text { Rainfall } \\
(\mathrm{mm})\end{array}$ & $\begin{array}{c}\text { Temperature } \\
(\text { soil surface })\end{array}$ \\
\hline May & 50 & 26 & 24.1 & 19 \\
June & 44 & 22 & 12.8 & 22 \\
July & 40 & 16 & - & 332 \\
August & 40 & 18 & - & 30 \\
September & 40 & 12 & - & 355 \\
\hline
\end{tabular}

\section{Results and Discussion}

Determination of sowing dates for maize varieties is crucial for better crop yield. Sowing date and variety treatments were statistically significant on the days to emergence tassel, days to anthesis, number of leaves, plant height, cob height, leaves above the cob, length of male flowers, stem diameter, plant dry weight, weight cob with pod, weight cob without pod, number of grain rows, number of grain per rows, grain yield, grain glucose, grain fructose, grain saccharose, grain raffinose and grain carbohydrates (Table 3). Table 3 (analysis of variance) shows that variety on the days to emergence tassel, days to anthesis, number of leaves, plant height, cob height, leaves above the cob, length of male flowers, stem diameter, plant dry weight, weight cob with pod, ear weight without pod, number of grain rows, number of grain per rows, grain glucose, grain fructose, grain saccharose, grain raffinose and grain carbohydrates were significant statistically at $1 \%$ probability level. Also, the obtained data (Table 3 ) shows that sowing date on days to anthesis, days to emergence tassel, plant height, cob height, leaves above the cob, length of male flowers, stem diameter, plant dry weight, weight cob with pod, ear weight without pod, number of grain per rows and grain raffinose were significant statistically at $1 \%$ probability level. In addition, it was noted that sowing date $\times$ variety on days to anthesis, leaves above the cob, length of male flowers, grain yield, grain glucose and grain glucose were significant statistically at $1 \%$ probability level (Table 3).

The highest days to emergence tassel, days to anthesis, number of leaves, plant height, cob height, number of leaves above the cob, length of male flowers, stem diameter, plant dry weight, weight cob with pod, weight cob without pod, number of grain rows, number of grains per row, grain yield, grain glucose, grain fructose, grain saccharose and grain raffinose were recorded in 'KSC403su' (57.50), 'KSC403su' (62.25), 'KSC403su' (12.64), 'Obsession' (145.99 cm), 'Obsession' (55.89 mm), 'Obsession' (7.80), 'Challenger' (44.68 mm), 'Chase' (17.52 mm), 'KSC403su' (457.42 gr), 'Chase' (329.49 gr), 'Temptation' (256.76 gr), 'Obsession' (18.61), 'Obsession' (39.16), 'Basin' (9.77 mg/gr), 'KSC403su' (26.90 mg/gr), 'Obsession' (13.86 mg/gr), 'KSC403su' (49.88 mg/gr) and 'Chase' $(0.71 \mathrm{mg} / \mathrm{gr})$ respectively (Table 4$)$.

The lowest days to emergence tassel, days to anthesis, number of leaves, plant height, cob height, number of leaves above the cob, length of male flowers, stem diameter, plant dry weight, weight cob with pod, weight cob without pod, number of grain rows, number of grains per row, grain yield, grain glucose, grain fructose, grain saccharose and grain raffinose were recorded in 'Challenger' (47.00), 'Challenger' (51.50), 'Challenger' (8.59), 'Challenger' (116.58 cm), 'Temptation' (32.30 mm), 'Challenger' (6.06), 'KSC403su' (38.78 mm), 'KSC403su' (16.44 mm), 'Challenger' (288.12 gr), 'KSC403su' (279.55 gr), 'KSC403su' (199.51 gr), 'Temptation' (16.20), 'Chase' (35.25), 'KSC403su' (7.25 $\mathrm{mg} / \mathrm{gr})$, 'Challenger' (13.35 mg/gr), 'Challenger' ( $7.65 \mathrm{mg} / \mathrm{gr})$, 'Challenger' (24.13 mg/gr) and 'Challenger' (0.00 mg/gr) respectively (Table 4). There is no significant difference among 'Chase' (9.27 t/ha), 'Temptation' (9.34 t/ha), 'Challenger' (9.52 t/ha) and 'Basin' ( $9.77 \mathrm{t} / \mathrm{ha})$ for grain yield.

The best sowing date for cultivation mentioned varieties in the hereby experiment was 15 June, because this time increased the number of leaves, days to anthesis, days to emergence tassel, stem diameter, leaves above the cob, grain yield, grain glucose, grain fructose, grain saccharose and grain raffinose. Varieties had similar grain yield, grain glucose, grain fructose, grain saccharose, grain raffinose, number of grains row and number of leaves at the two sowing dates. All varieties had similar grain yield except 'Obsession' and 'KSC403su' (Table 4).

Applying the optimum sowing date for maize cultivars has a positive effect on a grain yield and physiological index in maize. The study revealed that both sowing date and cultivar had significant effect on grain yield in applied sweet maize varieties under the field conditions. Similar results have been obtained where seeding dates and varieties significantly influenced on physiological characteristics, yield and component yield (Quayyum and Raquibullah, 1987; Abdul Rahman et al., 2001; Nielson et al., 2002). In the current study sowing date $\times$ cultivar interaction significant affected days to anthesis, leaves above the cob, length of male flowers, grain yield, grain glucose, grain raffinose. Plants at optimum sowing date (15 June) performed higher yield; 'Basin' produced a higher grain yield (about 9.77 t/ha), while 'KSC403su' produced the lowest quantity $(7.25 \mathrm{t} / \mathrm{ha})$. Plants at optimum sowing date (15 June) performed the high grain raffinose; 'Chase' produced a higher grain raffinose (about $0.71 \mathrm{mg} / \mathrm{gr}$ ), while 'Challenger' produced the lowest $(0.00 \mathrm{mg} / \mathrm{gr})$. This result is in agreement with findings of Otegui et al. (1995), saying that optimum planting date resulted in higher grain yield compared with early and late planting dates because of higher cob numbers and greater kernel numbers per plant.

In conclusions, overall, the best planting date for the six sweet corn varieties tested was 15 June and the height yield was obtained for the variety 'Basin'. 
Table 3. Analysis of variance for physiological characteristics, yield and component yield traits in the sowing date and variety treatments

\begin{tabular}{|c|c|c|c|c|c|c|c|c|}
\hline \multicolumn{9}{|c|}{ Mean Square (MS) } \\
\hline Sources change & df & $\begin{array}{l}\text { Days to } \\
\text { emergence tassel }\end{array}$ & $\begin{array}{l}\text { Days to } \\
\text { anthesis }\end{array}$ & $\begin{array}{c}\text { Number of } \\
\text { leaves }\end{array}$ & $\begin{array}{l}\text { Plant } \\
\text { height }\end{array}$ & $\begin{array}{l}\text { Cob } \\
\text { height }\end{array}$ & $\begin{array}{c}\text { Leaves } \\
\text { above the } \\
\text { cob }\end{array}$ & $\begin{array}{l}\text { Length of male } \\
\text { flowers }\end{array}$ \\
\hline Replication & 3 & $3.13^{*}$ & 5.02 & 0.95 & $115.46^{* *}$ & 5.38 & 0.10 & 3.95 \\
\hline Sowing date (D) & 1 & $111.02^{* *}$ & $85.33^{* *}$ & 0.73 & $6295.21^{*}$ & $1428.99^{* *}$ & $26.70^{* *}$ & $135.34^{*}$ \\
\hline First error & 3 & 0.24 & 0.39 & 0.63 & 333.99 & 40.92 & 0.15 & 7.07 \\
\hline Variety $(\mathrm{V})$ & 5 & $94.12^{* *}$ & $106.43^{* *}$ & $90.92^{* *}$ & $1340.50^{* *}$ & $726.77^{* *}$ & $3.16^{* *}$ & $74.88^{* *}$ \\
\hline $\mathrm{D} \times \mathrm{V}$ & 5 & 0.72 & $5.48^{*}$ & 1.50 & 61.70 & 16.48 & $0.22^{* *}$ & $13.32^{* *}$ \\
\hline Error & 30 & 1.12 & 1.89 & 0.58 & 101.98 & 23.88 & 0.06 & 2.72 \\
\hline $\mathrm{CV}$ & & 2.01 & 2.41 & 6.98 & 7.92 & 11.72 & 3.45 & 3.96 \\
\hline \multicolumn{9}{|c|}{ Mean Square (MS) } \\
\hline Sources change & $\mathrm{df}$ & $\begin{array}{c}\text { Stem } \\
\text { diameter }\end{array}$ & $\begin{array}{l}\text { Plant dry } \\
\text { weight }\end{array}$ & $\begin{array}{c}\text { Weight cob with } \\
\text { pod }\end{array}$ & $\begin{array}{l}\text { Ear weight without } \\
\text { pod }\end{array}$ & \multicolumn{2}{|c|}{$\begin{array}{l}\text { Number of grain } \\
\text { rows }\end{array}$} & $\begin{array}{l}\text { Number of grain } \\
\text { per rows }\end{array}$ \\
\hline Replication & 3 & 2.03 & 3179.58 & 1540.89 & 388.17 & \multicolumn{2}{|c|}{0.86} & 2.90 \\
\hline Sowing date (D) & 1 & $59.83^{* *}$ & $6290.91^{*}$ & $9080.86^{* *}$ & $4497.04^{* *}$ & \multicolumn{2}{|c|}{1.30} & $320.85^{* *}$ \\
\hline First error & 3 & 0.44 & 2810.59 & 220.29 & 91.21 & \multicolumn{2}{|c|}{2.25} & 2.72 \\
\hline Variety $(\mathrm{V})$ & 5 & $4.09^{* *}$ & $3222.91^{* *}$ & 3049.93 & $2900.82^{* *}$ & \multicolumn{2}{|c|}{$5.83^{* *}$} & $29.04^{* *}$ \\
\hline $\mathrm{D} \times \mathrm{V}$ & 5 & 0.39 & 2484.66 & 1635.36 & 507.53 & \multicolumn{2}{|c|}{0.43} & 8.92 \\
\hline Error & 30 & 0.54 & 3913.54 & 904.78 & 634.51 & \multicolumn{2}{|c|}{0.44} & 5.01 \\
\hline $\mathrm{CV}$ & & 4.27 & 16.53 & 9.76 & 10.84 & \multicolumn{2}{|c|}{3.90} & 3.15 \\
\hline \multicolumn{9}{|c|}{ Mean Square (MS) } \\
\hline Sources change & $\mathrm{df}$ & $\begin{array}{l}\text { Grain } \\
\text { yield }\end{array}$ & $\begin{array}{c}\text { Grain } \\
\text { glucose }\end{array}$ & $\begin{array}{c}\text { Grain } \\
\text { fructose }\end{array}$ & $\begin{array}{c}\text { Grain } \\
\text { saccharose }\end{array}$ & \multicolumn{2}{|c|}{$\begin{array}{l}\text { Grain } \\
\text { raffinose }\end{array}$} & $\begin{array}{c}\text { Grain } \\
\text { carbohydrates }\end{array}$ \\
\hline Replication & 3 & 0.351 & 0.700 & 0.065 & 1.200 & \multicolumn{2}{|c|}{0.0006} & 0.06 \\
\hline Sowing date (D) & 1 & 0.006 & 0.333 & 0.025 & 0.460 & \multicolumn{2}{|c|}{$0.0075^{*}$} & 0.08 \\
\hline First error & 3 & 0.157 & 0.167 & 1.948 & 0.255 & \multicolumn{2}{|c|}{0.0003} & 0.03 \\
\hline Variety $(V)$ & 5 & 0.198 & $186.647^{* *}$ & $42.388^{* *}$ & $676.173^{* *}$ & \multicolumn{2}{|c|}{$0.8466^{* *}$} & $2090.15^{* *}$ \\
\hline $\mathrm{D} \times \mathrm{V}$ & 5 & $0.143^{* *}$ & $12.933^{* *}$ & 1.617 & 12.570 & \multicolumn{2}{|c|}{$0.0275^{* *}$} & 14.03 \\
\hline Error & 30 & 0.286 & 2.037 & 0.472 & 5.156 & \multicolumn{2}{|c|}{0.0008} & 7.00 \\
\hline $\mathrm{CV}$ & & 6.04 & 7.229 & 6.907 & 6.632 & \multicolumn{2}{|c|}{9.5752} & 3.86 \\
\hline
\end{tabular}

***: Significant at $5 \%$ and $1 \%$ probability levels, respectively and ns: Non-significant

Table 4. Mean comparison of physiological characteristics, yield and component yield traits in interaction effect of sowing date and variety treatments

\begin{tabular}{|c|c|c|c|c|c|c|}
\hline Sowing date & $\begin{array}{c}\text { Days to emergence } \\
\text { tassel } \\
\end{array}$ & $\begin{array}{l}\text { Days to } \\
\text { anthesis }\end{array}$ & $\begin{array}{c}\text { Number of } \\
\text { leaves }\end{array}$ & $\begin{array}{c}\text { Plant height } \\
(\mathrm{cm})\end{array}$ & $\begin{array}{c}\text { Cob height } \\
(\mathrm{mm})\end{array}$ & $\begin{array}{c}\text { Leaves above } \\
\text { the cob }\end{array}$ \\
\hline 15 June & $54.17 \mathrm{a}$ & $58.29 \mathrm{a}$ & $10.79 \mathrm{a}$ & $116.05 b$ & $36.25 b$ & $7.88 \mathrm{a}$ \\
\hline 1 July & $51.12 \mathrm{~b}$ & $55.62 b$ & $11.04 \mathrm{a}$ & $138.95 \mathrm{a}$ & $47.17 \mathrm{a}$ & $6.39 \mathrm{~b}$ \\
\hline \multicolumn{7}{|c|}{ Variety } \\
\hline 'Chase' & $52.75 \mathrm{c}$ & $55.87 \mathrm{~d}$ & $10.82 \mathrm{~b}$ & $116.18 b$ & $35.70 \mathrm{~d}$ & $7.19 \mathrm{~b}$ \\
\hline 'Temptation' & $51.75 \mathrm{c}$ & $55.50 \mathrm{~d}$ & $10.02 \mathrm{c}$ & $119.10 \mathrm{~b}$ & $32.30 \mathrm{~d}$ & $7.01 \mathrm{~b}$ \\
\hline 'Challenger' & $47.00 \mathrm{~d}$ & $51.150 \mathrm{e}$ & $8.59 \mathrm{~d}$ & $116.58 \mathrm{~b}$ & $34.04 d$ & $6.06 c$ \\
\hline 'Basin' & $52.62 c$ & $57.37 \mathrm{c}$ & $11.02 b$ & $126.37 \mathrm{~b}$ & $42.30 \mathrm{c}$ & $7.01 \mathrm{~b}$ \\
\hline 'Obsession' & $54.25 b$ & $59.25 b$ & $12.39 \mathrm{a}$ & $145.99 a$ & $55.89 a$ & $7.80 \mathrm{a}$ \\
\hline 'KSC403su’ & $57.50 \mathrm{a}$ & $62.25 \mathrm{a}$ & $12.64 a$ & $140.79 a$ & $50.04 \mathrm{~b}$ & $7.72 \mathrm{a}$ \\
\hline Sowing date & $\begin{array}{l}\text { Length of male } \\
\text { flowers }(\mathrm{cm})\end{array}$ & $\begin{array}{c}\text { Stem } \\
\text { diameter }\end{array}$ & $\begin{array}{c}\text { Plant dry } \\
\text { weight (gr) }\end{array}$ & $\begin{array}{l}\text { Weight cob with } \\
\text { pod (gr) }\end{array}$ & $\begin{array}{l}\text { Weight cob without } \\
\text { pod (gr) }\end{array}$ & $\begin{array}{l}\text { Number of } \\
\text { grains row }\end{array}$ \\
\hline 15 June & $39.95 \mathrm{~b}$ & $18.41 \mathrm{a}$ & $342.22 \mathrm{~b}$ & $254.53 \mathrm{~b}$ & $201.65 \mathrm{~b}$ & $16.86 \mathrm{a}$ \\
\hline 1 July & $43.30 \mathrm{a}$ & $16.18 \mathrm{~b}$ & $414.62 \mathrm{a}$ & $351.52 \mathrm{a}$ & $262.88 \mathrm{a}$ & $17.19 \mathrm{a}$ \\
\hline \multicolumn{7}{|c|}{ Variety } \\
\hline 'Chase' & $39.15 c$ & $17.52 \mathrm{a}$ & $353.86 \mathrm{~b}$ & $329.49 a$ & $240.85 \mathrm{ab}$ & $16.94 b$ \\
\hline ‘Temptation' & $45.38 \mathrm{a}$ & $17.45 \mathrm{~b}$ & $337.80 \mathrm{bc}$ & $326.19 a$ & $256.76 \mathrm{a}$ & $16.20 \mathrm{c}$ \\
\hline 'Challenger' & $44.68 \mathrm{a}$ & $16.04 \mathrm{c}$ & $288.12 c$ & $292.54 b c$ & $227.77 b$ & $16.55 \mathrm{bc}$ \\
\hline 'Basin' & $38.88 \mathrm{c}$ & $17.44 \mathrm{~b}$ & $400.07 \mathrm{ab}$ & $315.47 \mathrm{ab}$ & $238.70 \mathrm{ab}$ & $17.22 b$ \\
\hline 'Obsession' & $42.90 \mathrm{~b}$ & $17.11 \mathrm{~b}$ & $433.27 \mathrm{a}$ & $304.89 \mathrm{abc}$ & $230.00 \mathrm{~b}$ & $18.61 \mathrm{a}$ \\
\hline 'KSC403su’ & $38.78 \mathrm{c}$ & $18.22 \mathrm{c}$ & $457.42 \mathrm{a}$ & $279.55 c$ & $199.51 \mathrm{c}$ & $16.61 \mathrm{bc}$ \\
\hline Sowing date & $\begin{array}{c}\text { Number of grains } \\
\text { per row }\end{array}$ & $\begin{array}{c}\text { Grain yield } \\
(\mathrm{t} / \mathrm{ha})\end{array}$ & $\begin{array}{l}\text { Grain glucose } \\
(\mathrm{mg} / \mathrm{gr})\end{array}$ & $\begin{array}{c}\text { Grain fructose } \\
(\mathrm{mg} / \mathrm{gr})\end{array}$ & $\begin{array}{c}\text { Grain saccharose } \\
(\mathrm{mg} / \mathrm{gr})\end{array}$ & $\begin{array}{c}\text { Grain raffinose } \\
(\mathrm{mg} / \mathrm{gr})\end{array}$ \\
\hline 15 June & $33.80 \mathrm{~b}$ & $8.86 \mathrm{a}$ & $24.34 \mathrm{a}$ & $10.05 \mathrm{a}$ & $38.23 \mathrm{a}$ & $0.023 \mathrm{a}$ \\
\hline 1 July & $38.98 \mathrm{a}$ & $8.84 \mathrm{a}$ & $24.26 a$ & $10.10 \mathrm{a}$ & $38.12 \mathrm{a}$ & $0.020 \mathrm{a}$ \\
\hline \multicolumn{7}{|c|}{ Variety } \\
\hline 'Chase' & $35.25 \mathrm{~cd}$ & $9.27 \mathrm{a}$ & $22.78 b$ & $9.15 \mathrm{c}$ & $38.13 b$ & $0.71 \mathrm{a}$ \\
\hline 'Temptation' & $35.96 \mathrm{bcd}$ & $9.34 \mathrm{a}$ & $16.35 \mathrm{e}$ & $8.90 \mathrm{c}$ & $28.30 \mathrm{~d}$ & $0.47 \mathrm{c}$ \\
\hline 'Challenger' & $33.70 \mathrm{ab}$ & $9.52 \mathrm{a}$ & $13.35 \mathrm{f}$ & $7.65 \mathrm{~d}$ & $24.13 e$ & $0.00 \mathrm{~d}$ \\
\hline 'Basin' & $37.70 \mathrm{ab}$ & $9.77 \mathrm{a}$ & $18.18 \mathrm{~d}$ & $8.61 \mathrm{c}$ & $29.39 \mathrm{~d}$ & $0.00 \mathrm{~d}$ \\
\hline 'Obsession' & $39.16 \mathrm{a}$ & $7.93 b$ & $20.92 c$ & $13.86 \mathrm{a}$ & $35.62 c$ & $0.00 \mathrm{~d}$ \\
\hline 'KSC403su' & $36.56 \mathrm{bc}$ & $7.25 c$ & $26.90 \mathrm{a}$ & $11.49 \mathrm{~b}$ & $49.88 \mathrm{a}$ & $0.54 b$ \\
\hline
\end{tabular}

Means followed by same letters in each column have not significant difference at $5 \%$ probability 


\section{References}

Ahmad N, Waheed A, Hamid FS (2001). Different sowing dates of maize cultivars and their performance. Pakistan Journal of Biological Sciences 1:106-108.

Abdul Rahman AM, Lazim Mogboul E, AbdollatiefEN (2001). Effects of sowing date and cultivar on the yield and yield components of maize in Northern Sudan. Proceedings of the Seventh Eastern and Southern Africa. Regional Maize Conference, February11-15, Nairobi, Kenya pp 295-298.

Banziger M,DeMeyer (2002). Collaborative maizevariety development for stress-prone environments in Southern Africa. In: Cleveland DA, Soleri D (Eds). Farmers, Scientists and Plant Breeding: Integrating Knowledge and Practice. CABI, Oxon, UK pp 269-296.

Begna SH, Hamilton RI, Dwyer LM, Stewart DW, Smith DL (2000). Variability among maize hybrids differing in canopy architecture for above-ground dry matter and grain yield. Maydica 45(2):135-141.

Berzsenyi Z, Lap DQ (2001). Effect of sowing time and N fertilization on the yield and yield stability of maize (Zea mays L.) hybrids between 1991-2000. Novenytermeles Hungary 50:309-331.

Cirilo AG, Andrade FH (1996). Sowing date and maize productivity. I. Cropgrowth and dry matter partitioning. CropScience 34:1039-1043.

Cox WJ, Cherney DJR, Hanchar JJ (1998). Row spacing, hybrid and plant density effects on corn silage yield and quality. Journal of Production Agriculture 11:128-134.

Dehghani H, Ebadi A, Yousefi A (2006). Biplot analysis of genotype by environment interaction for barley yield in Iran. Agronomy Journal 98(2):388-393.

Duncan WJ, Hatfield AL, RaglandJL (1965). The growth and yield of corn. II. Daily growth of corn kernels. Agronomy Journal 57:221-223.

Duvick DN (1951). Development and duration of maize endosperm. PhD Thesis Washington UniversitySt. Louis.

Elkarouri MOH, Mansi MG (1980). Performance of sorghum (Sorghum vulgare) and maize (Zea mays) as forage in irrigated saline soils of the Sudan. Explorer Agriculture 16:431-436.

El-Koomy MBA (2005). Significance of some agronomic indices in maize breeding program. $\mathrm{PhD}$ Thesis, Agronomy Department Factuality of Agriculture Ain Shams University.

Gardner FP, Valle R, Mc Cloud DE (1990). Yield characteristics of ancient races of maize compared to a modern hybrid. Agronomy Journal 82(5):864-868.

Gerpacio VR, Pingali PL (2007). Tropical and subtropical maize in Asia: production systems, constraints and research priorities. CIMMYT, Mexico.

Golbashy M, Ebrahimi M, Khavari Khorasani S, Choucan R (2010). Evaluation of drought tolerance of some corn (Zea mays $\mathrm{L}$.) hybrids in Iran. African Journal of Agricultural Resources 5(19):2714-2719.

Grzesiak S (2001). Genotypic variation between maize (Zea mays L.) singlecross hybrids in response to drought stress. Acta Physiologiae Plantarum 23(4):443-456.

Hicks DR, Harrington JD, Mcgahen JH (1993). Maximizing the advantages of early corn planting. National Corn Handbook, Crop Management. Purdue University Cooperative Extension Service. West
Lafayette, Indiana. NCH-35.

Imam AI (1966). Maize agronomy experiment. Annual Report (1965/66). Hudeiba Research Station, Sudan pp 19-20.

Ihsan H, Khalil IH, Rehman H, Iqbal M (2005). Genotypic variability for morphological traits among exotic maize hybrids. Sarhad Journal of Agriculture 21(4):599-602.

Johnson DR, TannerJW (1972). Calculation of the rate and duration of the grain fillingin corn (ZeamaysL.). CropScience 12(4):845-846.

Jones RJ, Gengenback BG, Cardwell VB (1981). Temperature effects on in vitro kernel development of maize. CropScience 21(5):761-766.

Mc Cormick SJ (1974). The effect of sowing date on maize (Zea mays L.) development and yield of silage and grain. Proceedings of the Agronomy Society of NewZealand 1:51-65.

Najeeb S, Sheikh FA, Ahangar MA, Teli NA (2011). Popularization of sweet corn (Zea mays L. saccharata) under temperate conditions to boost the socieconomic conditions. Maize Genetic Cooperation Newsletter(85).

Nielson RL, Thomison PR, Brown GA, Halter AL, Wells J, Wuethrich KL (2002). Delayed planting date effects on flowering and grain maturation of corn. Agronomy Journal 94:549-558.

Norwood CA (2001). Planting date, hybrid maturity and plant density effect on soil water depletion and yield of dry land corn. Agronomy Journal 93:1034-1042.

Otegui ME, Nicolini MG, Ruiz RA, Dodds PA (1995). Sowing date effects on grain yield components for different maize genotypes. Agronomy Journal 87:29-33.

Outtar S, Jones RJ, Crookston RK (1987). Effect of water deficit during grain filling on the pattern of maize kernel growth and development. CropScience 27:726-730.

Quayyum MA, Raquibullah SM (1987). Effect of seeding dates on the grain yield and yield attributes of four entries of maize in Bangladesh. Annual Bangladesh Science Conference, Dhaka, Bangladesh.

Sabaghnia DNH, Sabaghpour SH (2008). Graphic analysis of genotype $\times$ environment interaction of lentil yield in Iran. Agronomy Journal 100:760-764.

Sadek SE, El-Sherbieny HYS, Ahmed MA, Younis MA (1994). Evaluation of eight yellow maize (Zea mays L.) hybrid grown in Egypt. 1. Growth analysis and grain yield components. Journal Agriculture Science Mansoura University 19:41544160.

Sárvári M, FutóZ (2000). Correlation between the sowing date, yield and grain moisture content of maize hybrids on chernozem soil. Debreceni Egyetem AgrártudományiKözleményekJournal 1:32-41.

SAS Institute Inc (2002). The SAS System for Windows, Release 9.0. Statistical Analysis 810 Systems Institute, Cary NC USA.

Welsh J (1981). Fundamentals of plant breeding and genetics. John Wiley \& Sons, New York.

Xue J, Liang Z, Ma G, Lu H, Ren J (2002). Population physiological indices on density tolerance of maize in different plant type. Crop Science 13:55-59.

Yan W, Kang MS, Ma B, Woods S, Cornelius PL (2007). GGE Biplot vs. AMMI analysis of genotype-by-environment data. Crop Science 47:643-655. 